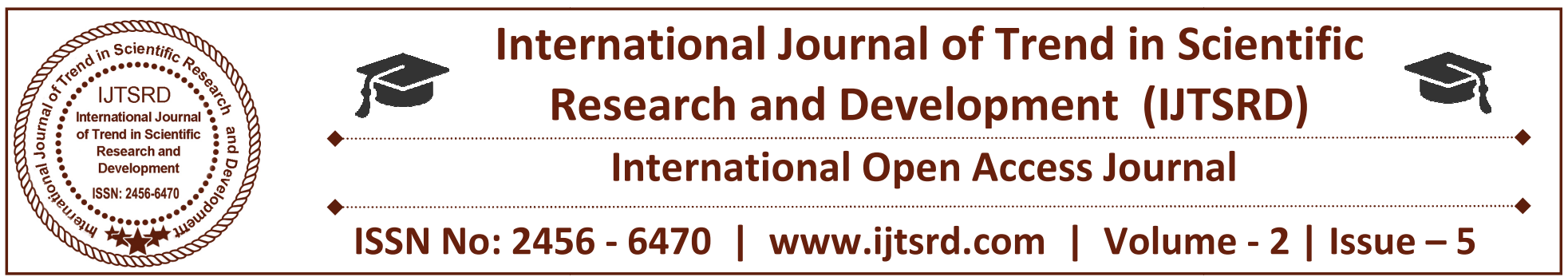

\title{
To Determine the Mechanical Properties of Concrete by Using Glass Fibre and Polypropylene Fibre
}

\author{
Sheikh Gowhar Nazir ${ }^{1}$, Mr. Misbah Danish ${ }^{2}$ \\ ${ }^{1}$ Student, ${ }^{2}$ Assistant Professor, ${ }^{1,2}$ Department of Civil Engineering, \\ Al-Falah School of Engineering and Technology, Al-Falah University, \\ Dhauj, Faridabad, Haryana, India
}

\section{ABSTRACT}

Concrete is the most widely used construction material has several desirable properties like high compressive strength, stiffness and durability under usual environmental factors. At the same time concrete is brittle and weak in tension. Plain concrete has two deficiencies, low tensile strength and a low strain at fracture. These shortcomings are generally overcome by reinforcing concrete. Normally reinforcement consists of continuous deformed steel bars or pre-stressing tendons. The advantage of reinforcing and pre-stressing technology utilizing steel reinforcement as high tensile steel wires have helped in overcoming the incapacity of concrete in tension but the ductility magnitude of compressive strength. Fibre reinforced concrete (FRC) is a concrete made primarily of hydraulic cements, aggregates and discrete reinforcing fibres. FRC is a relatively new material. This is a composite material consisting of a matrix containing a random distribution or dispersion of small fibres, either natural or artificial, having a high tensile strength. Due to the presence of these uniformly dispersed fibres, the cracking strength of concrete is increased and the fibres acting as crack arresters. Plain concrete possess very low tensile strength, limited ductility and little resistance to cracking. Internal micro cracks are inherently present in concrete and its poor tensile strength is due to propagation of such micro cracks. Fibres when added in certain percentage in the concrete improve the strain properties well as crack resistance, ductility, as flexure strength and toughness. Mainly the studies and research in fibre reinforced concrete has been devoted to steel fibres. In recent times, glass fibres have also become available, which are free from corrosion problem associated with steel fibres. The present paper outlines the experimental investigation conducts on the use of glass fibres with structural concrete. CEM-FILL anti crack, high dispersion, alkali resistance glass fibre of diameter 14 micron, having an aspect ratio 857 was employed in percentages, varying from 0.33 to1 percentage by weight in concrete and the properties of this FRC (fibre reinforced concrete) like compressive strength, flexure strength, toughness, modulus of elasticity were studied.

KEYWORD: glass fibre, compressive strength, workability

\section{INTRODUCTION}

\subsection{GENRAL}

Concrete is the most widely used construction material has several desirable properties like high compressive strength, stiffness and durability under usual environmental factors. At the same time concrete is brittle and weak in tension. Plain concrete has two deficiencies, low tensile strength and a low strain at fracture. These shortcomings are generally overcome by reinforcing concrete. Normally reinforcement consists of continuous deformed steel bars or pre-stressing tendons. The advantage of reinforcing and pre-stressing technology utilizing steel reinforcement as high tensile steel wires have helped in overcoming the incapacity of concrete in tension but the ductility magnitude of compressive strength. Fibre Reinforced Concrete (FRC) is a concrete made primarily of hydraulic cements, aggregates and discrete reinforcing fibres. 
FRC is a relatively new material. This is a composite material consisting of a matrix containing a random distribution or dispersion of small fibres, either natural or artificial, having a high tensile strength. Due to the presence of these uniformly dispersed fibres, the cracking strength of concrete is increased and the fibres acting as crack arresters.

Glass-fibre reinforced concrete (GRC) is a material made of a cement matrix composed of cement, sand, water and admixtures, in which short length glass fibres are dispersed. It has been widely used in the construction industry for non-structural elements, like façade panels, piping and channels.

GRC offers many advantages, such as being lightweight, fire resistance, good appearance and strength. In this study trial tests for concrete with glass fibre and without glass fibre are conducted to indicate the differences in compressive strength and flexural strength by using cubes of varying sizes. Various applications of GFRC shown in the study, the experimental test results, techno-economic comparison with other types, as well as the financial calculations presented, indicate the tremendous potential of GFRC as an alternative construction material.

\subsection{GLASS FIBRES}

It is a chemically inorganic fibre, obtained from molten mass of specific composition. All glass fibres are derived from composition of silica which are available in virtually unlimited supply. They exhibit useful bulk properties like, hardness, resistance to chemical attack,

inertness, strength, flexibility and stiffness.Glassfibre products have excellent heat and sound insulation qualities.

\section{TYPES OF GLASS FIBRES}

$\begin{array}{ll}\text { A- GLASS } & \text { (Close to normal glass) } \\ \text { C- GLASS } & \text { (Resistant to chemical attack) } \\ \text { E- GLASS } & \text { (Insulation to electricity) } \\ \text { AR- GLASS } & \text { (Alkali resistant) } \\ \text { S- GLASS } & \text { (High strength fibre) }\end{array}$

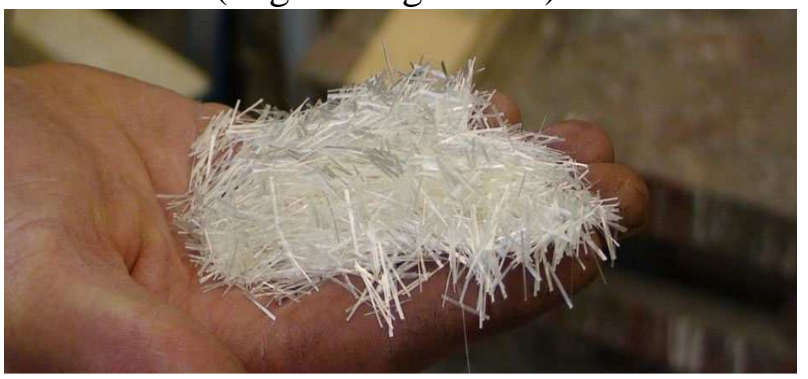

Fig. 1 glass fibr
Typical Tensile Strength Of Glass Fiber

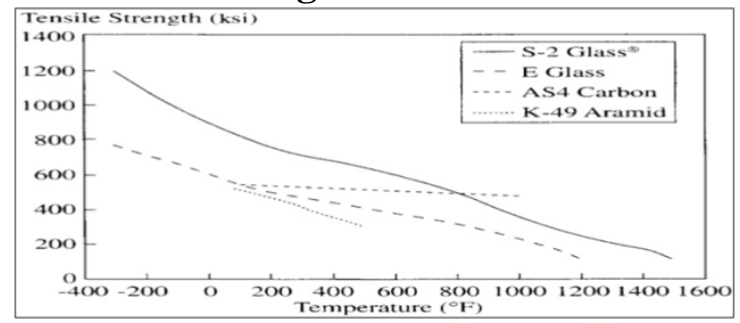

Unit conversion- $1 \mathrm{ksi}=6.89 \mathrm{~N} / \mathrm{mm}^{2}$

\section{ADVANTAGES/ LIMITATIONS OF GFRC}

The main advantages of GRC in comparison to concrete, plastic or steel are as follows:

1. It is versatile with great design flexibility. It can be provided in many colours, textures, patterns and surface finishes. Nearly any shape product can be formed.

2. Fibres are lightweight that minimizes the load added to existing structures.

3. Improved Chemical Resistance for example it has better chloride penetration resistance than steel.

4. It does not rust or corrode.

5. Improved shrinkage properties over plain concrete.

6. It is inorganic and does not add to the fire loading of a structure.

7. Good acoustic properties.

8. Low permeability that increases water or air pollution resistance; and it is environmentally friendly.

Some of the main limitations of GRC are:

1. It is more expensive than plain concrete.

2. GRC can lose some of its initial strength over long periods of time and this has to be taken into consideration during the design stage

3. It is manufactured as precast rather than on-site which means that forward planning is required.

\section{OBJECTIVES OF THE PROJECT}

$>$ To explore and assess the possibility of using waste glass in concrete in terms of its strength.

$>$ To have a comparative study of waste glasscrete concrete.

$>$ Avoid disposal of industrial glass waste.

$>$ Reduce Portland cement content in concrete, resulting in decreased emission of greenhouse gas and decreased use of natural raw materials.

$>$ Reduce sand content in concrete, resulting in decreased sand extraction and preservation of natural resources.

To assess the durability of concrete mix. To 
have comparative study of workability and change in weight density.

$>$ To assess the role of waste glass as a partial replacement to fine aggregate.

$>$ To compare the design parameters of glasscrete with plain cement concrete.

\section{LITERATURE REVIEW}

\section{A Study on Glass Fibre as an Additive in Concrete} to Increase Concrete Tensile Strength.: https://www.researchgate.net/publication/2811784 45.

This paper concludes that The addition of glass fibres into the concrete mixture marginally improves the compressive strength at 28 days. It is observed from the experimental results, that the compressive strength of concrete, flexural strength of concrete, splitting tensile strength of concrete increases with addition of Percentage of glass fibers. The $0.1 \%$ addition of glass fibers into the concrete shows better result in mechanical properties and durability

Experimental Studies on Glass Fiber Concrete American Journal of Engineering Research (AJER) e-ISSN: 2320-0847 p-ISSN: 2320-0936

The present study concluded that the addition of glass fibres at $0.5 \%, 1 \%, 2 \%$ and $3 \%$ of cement reduces the cracks under different loading conditions. It has been observed that the workability of concrete increases at $1 \%$ with the addition of glass fibre.

The increase in compressive strength, flexural strength, split tensile strength for M-20 grade of concrete at 7 and 28 days are observed to be more at $1 \%$. We can likewise utilize the waste product of glass as fibre. It has been observed that there is a gradual increase in compressive strength compare to the normal concrete. The workability of concrete decreases from $1 \%$ due to the addition of fibre. The compressive strength is very high at $1 \%$ having for 7 days is $20.76 \mathrm{~N} / \mathrm{mm}^{2}$ and for 28 days is $28.46 \mathrm{~N} / \mathrm{mm}^{2}$. The tensile strength is very high at $1 \%$ having for 7 days is $1.47 \mathrm{~N} / \mathrm{mm}^{2}$ and for 28 days is $2.94 \mathrm{~N} / \mathrm{mm}^{2}$. The split tensile strength is very high at $1 \%$ having for 7 days is $2.83 \mathrm{~N} / \mathrm{mm}^{2}$ and for 28 days is $3.92 \mathrm{~N} / \mathrm{mm}^{2}$.

STUDIES OF GLASS FIBER REINFORCED CONCRETE COMPOSITES. ISSN 2319 - 6009 www.ijscer.com Vol. 2, No. 3, August 2013 ㄷ 2013 IJSCER

Addition of glass fiber in reinforced concrete increases the toughness by using fiber content $0.67 \%$ and $1.25 \%$ steel. The modulus of elasticity of glass fiber reinforced concrete is increases $4.14 \%$ compared with conventional reinforced concrete. The percentage increase of compressive strength of various grades of glass fiber concrete mixes compared with 28 days compressive strength is observed $37 \%$. The percentage increase of flexure strength of various grades of glass fiber concrete mixes compared with 28 days compressive strength is observed $5.19 \%$.

Experimental studies on fiber reinforced concrete. Utkarsh R. Nishane. Int. Journal of Engineering Research and Application www.ijera.com ISSN: 2248-9622, Vol. 7, Issue 5, (Part -2) May 2017, pp.40-44

For glass and steel reinforcement, strength of concrete increased with, increased in fibre dosage up to $0.5 \%$ as compared to glass fibre, aramid fibre gives $48 \%$ more compressive strength, whereas when comparing aramid and steel fibre, aramid gives $66 \%$ increased compressive strength. Aramid reinforced concrete produce massive compressive strength as here, the aramid reinforced concrete is introducing compressive strength as equal to M35 grade in design of M20 grade.

Study of Glass Fibre Reinforced Concrete IOSR Journal of Mechanical and Civil Engineering (IOSR-JMCE) e-ISSN: 2278-1684,p-ISSN: 2320334X, Volume 13, Issue 3 Ver. VI (May- Jun. 2016), PP 58-61

The modulus of elasticity of glass fibre reinforced concrete is increases $4.14 \%$ compared with conventional reinforced concrete. The percentage increase of compressive strength of various grades of glass fibre concrete mixes compared with 28 days compressive strength is observed $37 \%$. The percentage increase of flexure strength of various grades of glass fibre concrete mixes compared with 28 days compressive strength is observed .19\%. Addition of glass fibre improves the toughness, flexural strength, ductility as well as compressive strength of concrete. A very small volume of glass fibre is required upto $0.33 \%$ of weight of cement content. Further addition may decrease the strength of concret

Experimental Study on Properties of Concrete by Using Ceramic Materials I international Journal of Engineering Trends and Technology (IJETT) Volume-43 Number-7 -January 2017

With the experimental studies by th researchers, the following conclusions can be drawn: 
Ceramic waste initially there is decrease of $23.32 \%$ in compressive strength of 7 days when partially replacement of $10 \%$, but after that while replacing $20 \%$ there is increase of $5.48 \%$ and with $30 \%$ there is increase of $14.56 \%$ increases respectively in initial compressive strength with respect to normal concrete mix. The reason behind this is that the ceramic waste (sand) behaves as micro filler in concrete. When the ceramic waste replaced as $10 \%$ the amount of micro filler is not enough to exhibit required strength but further increase in amount of ceramic waste (sand) fill more voids in concrete mix due to which the compressive strength increased.

Ceramic waste initially there is decrease $16.20 \%$ in compressive strength of 28days when partially replacement of $10 \%$, but after that while replacing
$20 \%$ there is increase of $4.2 \%$ and with $30 \%$ there is increase of $14.42 \%$ increases respectively in final compressive strength with respect to normal concrete.

To study the effect of the partial replacement of cement by using glass FIBRES \& fly ash in concrete. SSRG International Journal of Civil Engineering (SSRG-IJCE) - volume 3 Issue 5-May 2016

Conclusion of this paper is:

$>$ The percentage decreases in 28 days strength of concrete by replacement of cement with $5 \%$ glass FIBRE is only about $9 \%$

The percentage decreases in 28 days strength of concrete by replacement of cement

\section{METHODOLOGY}

The methodology adopted for achieving the desired objectives is shown in the form of flow chart given below:

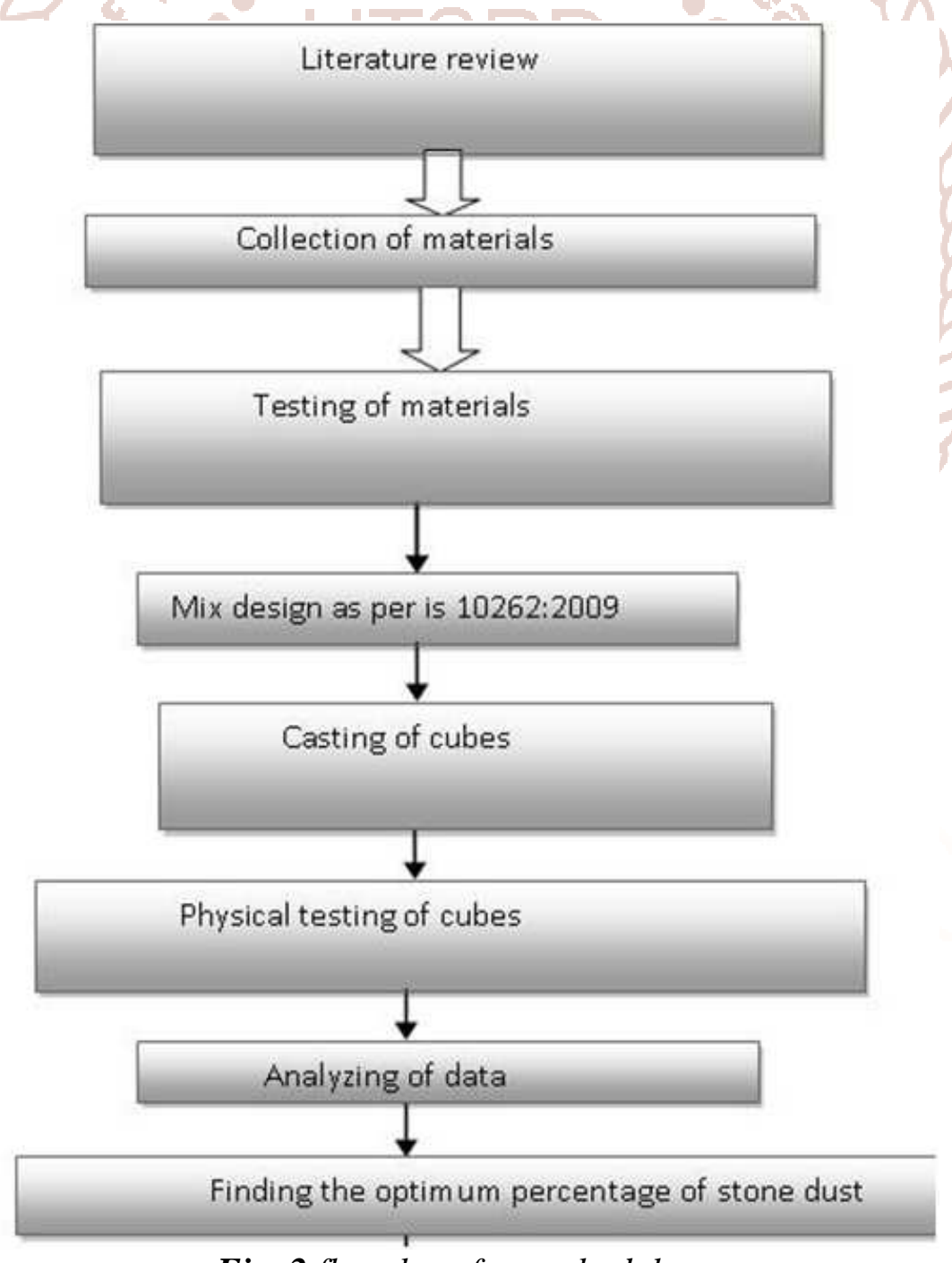

Fig. 2 flowchart for methodology 


\section{MATERIAL USED}

CEMENT-cement is a binding material used for filling the voids. It reacts with water to form gel which hardens into stone like structure, with passage of time. Portland Pozollona Cement (PPC) available in local market is used in investigation. It is conforming IS 1489 (PART-1 OF 1991) fly ash based specifications. Cement is having specific gravity of 3.15 .

COARSE AGGREGATES-the aggregates which passes through $75 \mathrm{~mm}$ IS sieve and retained on 4.75 $\mathrm{mm}$ IS sieve are termed as coarse aggregates. Crushed angular aggregates from a local source were used as coarse aggregate.

FINE AGGREGATES- the aggregates, most of which passes through $4.75 \mathrm{~mm}$ IS sieve and retained on 75 microns $(0.075 \mathrm{~mm})$ IS sieve. Zone 3 sand was used as fine aggregate whose specific gravity was found out to be 2.74 .

\begin{tabular}{|l|l|l|l|l|}
\hline \multirow{2}{*}{ IS Sieve } & \multicolumn{4}{|l|}{ Percentage passing for } \\
\cline { 2 - 5 } & $\begin{array}{l}\text { Grading Zone } \\
\text { I }\end{array}$ & $\begin{array}{l}\text { Grading } \\
\text { Zone II }\end{array}$ & $\begin{array}{l}\text { Grading } \\
\text { Zone III }\end{array}$ & $\begin{array}{l}\text { Grading } \\
\text { Zone IV }\end{array}$ \\
\hline $10 \mathrm{~mm}$ & 100 & 100 & 100 & 100 \\
\hline $4.75 \mathrm{~mm}$ & $90-100$ & $90-100$ & $90-100$ & $90-100$ \\
\hline $2.36 \mathrm{~mm}$ & $60-95$ & $75-100$ & $85-100$ & $95-100$ \\
\hline $1.18 \mathrm{~mm}$ & $30-70$ & $55-90$ & $75-100$ & $90-100$ \\
\hline $600 \mathrm{micron}$ & $15-34$ & $35-59$ & $60-79$ & $80-100$ \\
\hline $300 \mathrm{microns}$ & $5-20$ & $8-30$ & $12-40$ & $15-50$ \\
& & & & \\
\hline 150 microns & $0-10$ & $0-10$ & $0-10$ & \\
\hline & & & & \\
\hline
\end{tabular}

\section{Table-2}

WATER-locally available portable water is used.

GLASS FIBRE-glass fibre used with modulus of elasticity $72 \mathrm{GPa}$, filament diameter 14 microns and specific gravity

\section{MATERIAL TESTING CEMENT}

$>$ For examining suitability of cement the following tests were performed in laboratory-

Fineness test-this test is generally performed to check that proper grinding of cement has taken place or not. It is performed with IS sieve no. 9 and the residue left after sieving for 15 minutes should not be more than $10 \%$ of original weight. In our test result it was 7.3 gm for $100 \mathrm{gm}$ of cement.

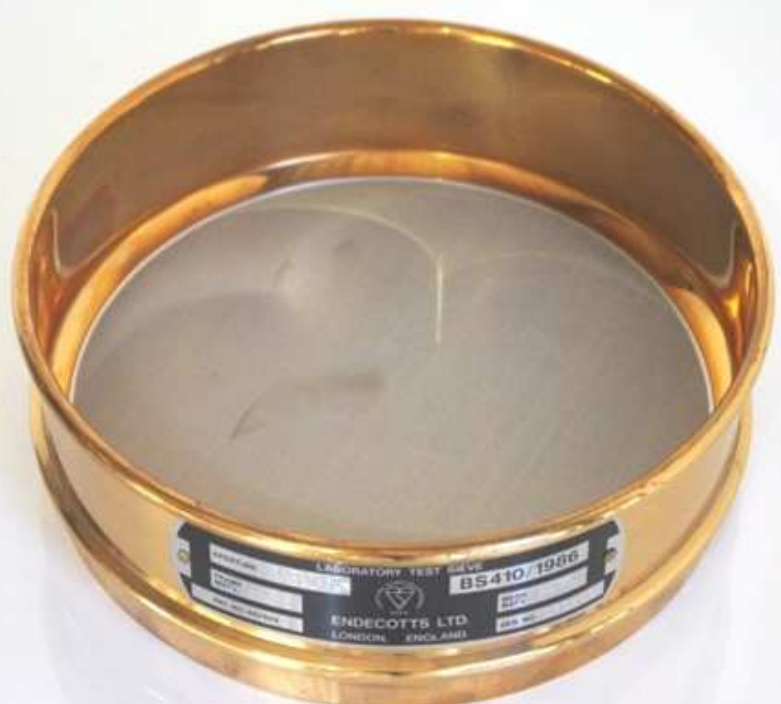

FIG. 3 IS sieve no. 9

Consistency test-this test is helpful for determining the percentage of water required for preparing cement paste for other tests like setting time, soundness and compressive strength of cement. This test is performed on Vicat apparatus. A plunger of $10 \mathrm{~mm}$ diameter is fixed to the lower end of movable for consistency test. The movable rod is released through the sample placed in a mould of $40 \mathrm{~mm}$ depth.For normal consistency depth of penetration of plunger should be $33 \mathrm{~mm}$ to $35 \mathrm{~mm}$ from the top of mould or $5 \mathrm{~mm}$ to $7 \mathrm{~mm}$ from bottom and it depends on water content used. If depth of penetration is not up to mark, then trial pastes should be made with varying quantities of water and repeated till standard penetration is obtained. We get standard penetration at weight of water equal to $30 \%$ the weight i.e. $120 \mathrm{gm}$ of water for $400 \mathrm{gm}$ of cement.

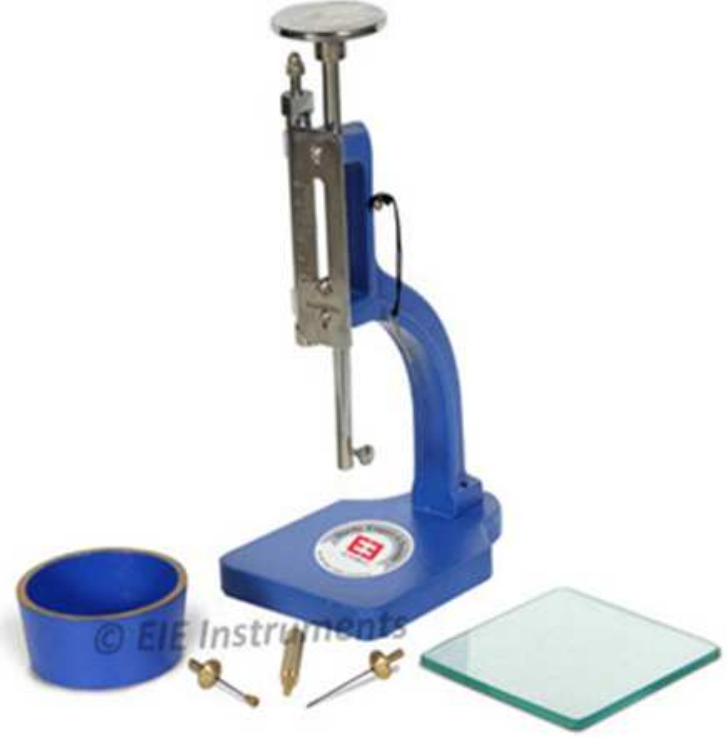

Fig.4 vicat's apparatus 


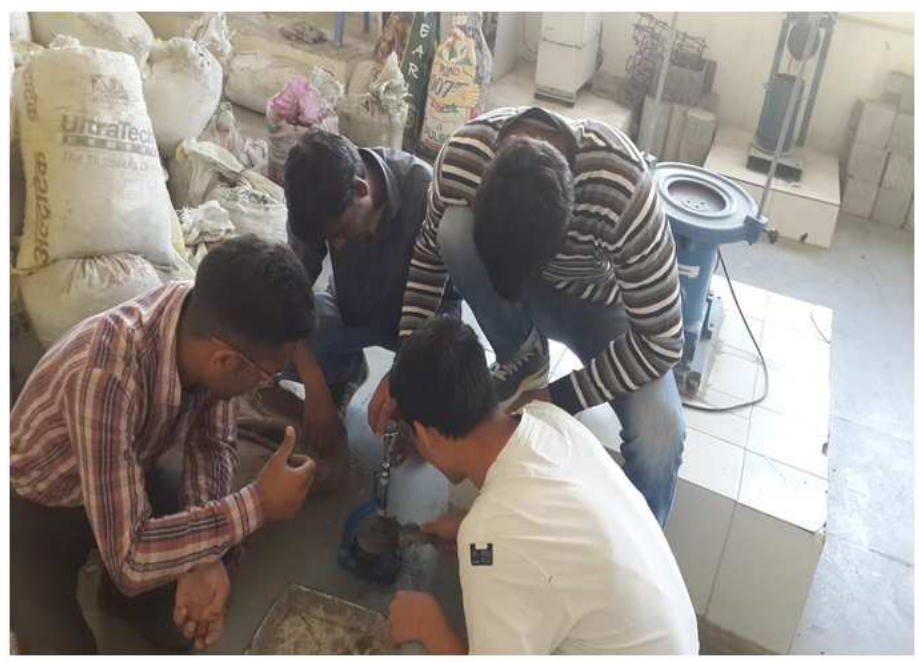

Fig5 determination of initial and final setting time

Initial and Final Setting Time test -cement when mixed with water forms paste which gradually becomes less plastic, and finally hard mass is obtained. Time to reach that stage is known as setting time. The time at which cement loses plasticity is known as initial setting time and the time at which cement become solid hard is termed as final setting time. It is also performed on Vicat's apparatus.

For initial setting time plunger of consistency test is replaced by initial setting time needle which is $1 \mathrm{~mm}$ square of $1.13 \mathrm{~mm}$ in diameter. Water content used is .85 times the water required for normal consistency i.e. $85 \times 120=102 \mathrm{gm}$. Needle is released and allowed to penetrate. Initially it penetrates completely. This process is continued till penetration is $33 \mathrm{~mm}$ to 35 $\mathrm{mm}$ from top of mould. The time is noted at which this standard penetration takes place. It should not be less than 10 minutes.

For final setting time needle is replaced by annular collar of base diameter $5 \mathrm{~mm}$. Movable rod is released and initially it will make impression on top surface of cement paste. The time is recorded at which collar fails to make impression on the surface. This time should not be more than 10 hours.

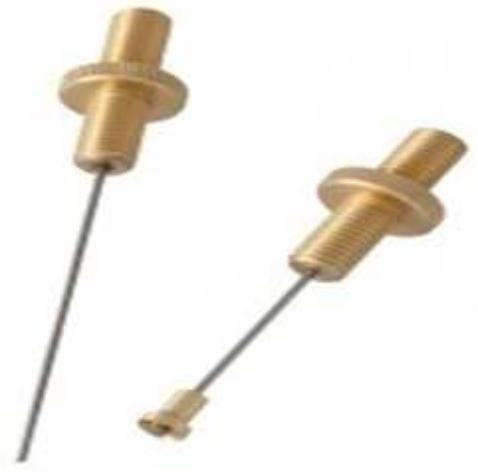

FIG. 6 Needle and annular collar
Soundness test-it is important that cement after setting shall not undergo any appreciable change in volume. Unsound cement is due to excess of lime and magnesia. Le-Chatlier is used to perform this test. This apparatus consists of a brass mould $30 \mathrm{~mm}$ diameter and $30 \mathrm{~mm}$ height. The thickness of mould is $.5 \mathrm{~mm}$ and a split in the mould not exceeding $.5 \mathrm{~mm}$ diameter. Two indicators $165 \mathrm{~mm}$ long are attached having pointed edges. In this test $100 \mathrm{gm}$ of cement is taken and sieved through IS sieve no. 9 and water is added at a rate of 0.72 times the water required for normal consistency i.e. $30 \mathrm{gm} \times .72=21.6 \mathrm{gm}$. This paste is filled in a mould, covered with glass plate and submerged in water for 24 hours. After taking out the mould from water the distance between points of indicators is noted. The mould is again submerged in water and heated in such a way that boiling point of water is reached in 25- 30 minutes and is heated for 3 hours. After cooling distance between two indicators is again taken and their difference must not exceed 10 $\mathrm{mm}$. In our test result it comes out to be $6.9 \mathrm{~mm}$.

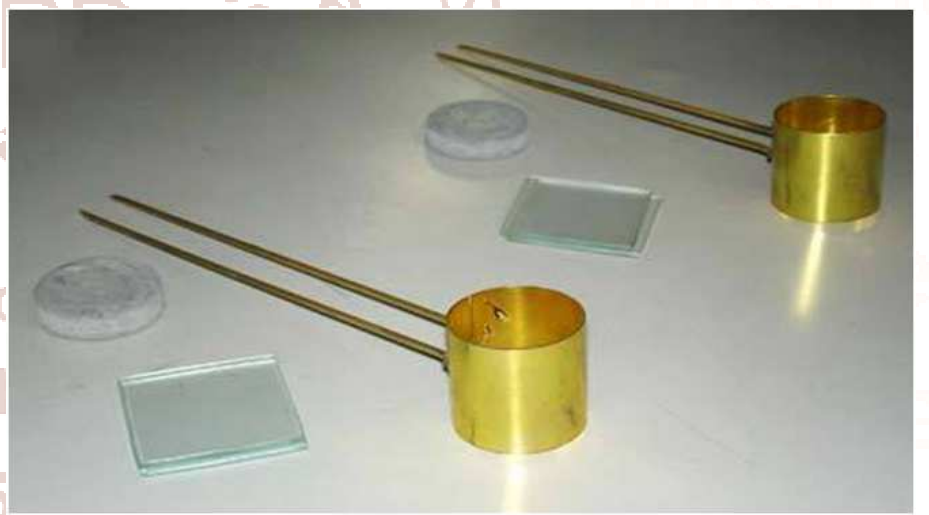

$$
\text { fig le-chatlier apparatus }
$$

\section{AGGREGATES-}

The various tests were performed on aggregates-

\section{Sieve analysis-}

This operation consists of dividing aggregate sample into various fractions consisting of particlesof same size. It may be defined as determining the proportion of different sizes of particles also known as gradation. Sieving can be done mechanically or by sieve shaker.Sieve analysis is also used for distinction between coarse and fine aggregates.We have used coarse aggregates of two sizes- $10 \mathrm{~mm}$ and $20 \mathrm{~mm}$.

$20 \mathrm{~mm}$ aggregates are those which passes through 20 $\mathrm{mm}$ IS sieve and retained on $16 \mathrm{~mm}$ IS sieve.Similarly $10 \mathrm{~mm}$ aggregates are those which passes through $10 \mathrm{~mm}$ IS sieve and retained on 4.75 mm IS sieve 
International Journal of Trend in Scientific Research and Development (IJTSRD) ISSN: 2456-6470

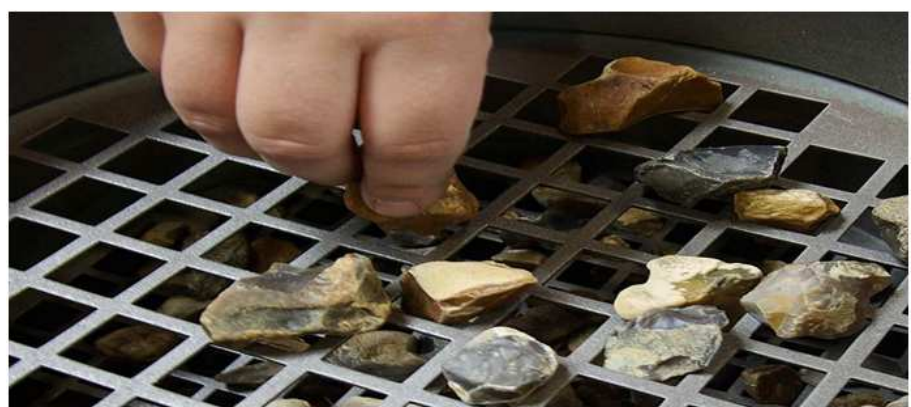

FIG. 8 Sieve analysis

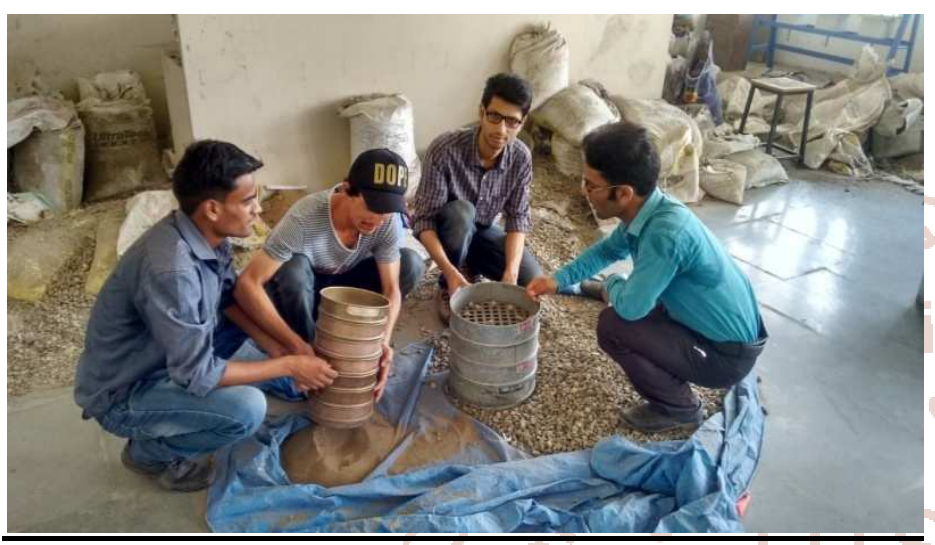

FIG.9 Sieveving process

\section{Water absorption test-}

The coarse aggregates not less than $2000 \mathrm{gm}$ are taken. The sample should be thoroughly washed to remove finer particles and dust, drained and then placed in the wire basket and immersed in distilled water at a temperature between 22 and $32^{\circ} \mathrm{C}$.After immersion, the entrapped air should be removed by lifting the basket and allowing it to drop 25 times in 25 seconds. The basket and sample should remain immersed for a period of $24+1 / 2$ hrs afterwards. The basket and aggregates should then be removed from the water, allowed to drain for a few minutes, after which the aggregates should be gently emptied from the basket on to one of the dry clothes and gently surface-dried with the cloth, transferring it to a second dry cloth when the first would remove no further moisture. The aggregates should be spread on the second cloth and exposed to the atmosphere away from direct sunlight till it appears to be completely surface-dry. The aggregates should be weighed (Weight 'A').The aggregates should then be placed in an oven at a temperature of 100 to $110^{\circ} \mathrm{C}$ for $24 \mathrm{hrs}$. It should then be removed from the oven, cooled and weighed (Weight 'B').

Formula used is Water absorption $=[(\mathbf{A}-\mathbf{B}) / \mathbf{B}] \mathbf{x}$ $100 \%$.

Two such tests should be done and the individual and mean results should be reported.

WATER ABSORPTION OF COARSE AGGREGATES
\begin{tabular}{|c|l|c|c|c|}
\hline S.No. & Determination No. & I & II & III \\
\hline 1 & $\begin{array}{l}\text { Weight of saturated } \\
\text { surface-dried sample } \\
\text { in g (A) }\end{array}$ & 2409 & 2380 & 2491 \\
\hline 2 & $\begin{array}{l}\text { Weight of oven-dried } \\
\text { sample in g(B) }\end{array}$ & 2404 & 2375 & 2426 \\
\hline 3 & $\begin{array}{l}\text { Water absorption } \\
=\frac{A-B}{B} \times 100 \%\end{array}$ & $\frac{5}{2404} \times 100=0.208 \%$ & $\frac{5}{2375} \times 100=0.210 \%$ & $\frac{5}{2486} \times 100=0.201 \%$ \\
\hline
\end{tabular}

$T A B L E-3$ Average value $=.206 \%$

Impact test-IS- 2386 part 4

This test is performed on aggregates impact testing machine which consists of a hammer which can be raised at a height of $380 \mathrm{~mm}$ from the top of the sample. The weight of hammer is $13.5 \mathrm{~kg}$ to $14 \mathrm{~kg}$.The oven dried sample of aggregates passing through 12.5 $\mathrm{mm}$ IS sieve and retained on $10 \mathrm{~mm}$ IS sieve are taken and put in a cylindrical mould in three layers tamping each layer 25 times with tamping rod. Weight (A) of sample in the mould is taken. Mould containing sample of aggregates is placed at the bottom of impact testing machine and 15 blows of hammer with interval not less than 1 second are given. After blows aggregate from mould are taken out and sieved with $2.36 \mathrm{~mm}$ IS sieve. Fraction passing through sieve is weighed as (B).

\section{Aggregate impact value $=(B / A) \times 100$}

$A=372 \mathrm{gm} B=58 \mathrm{gm}$ Impact value $=15.6 \%$

This result shows that aggregates are very strong.

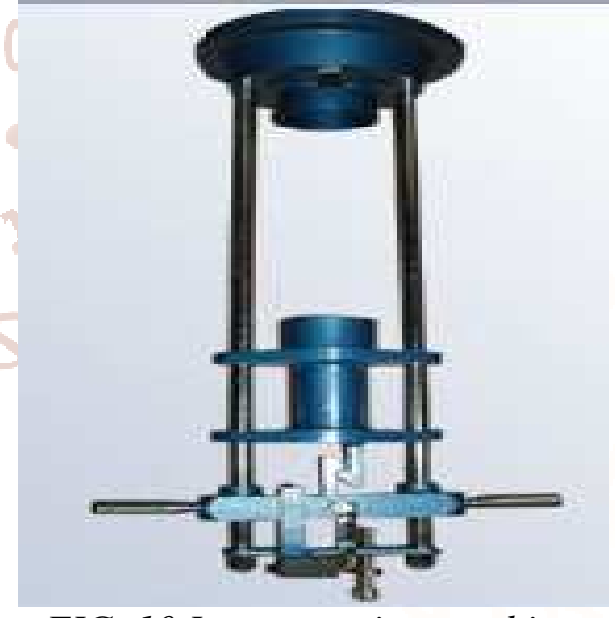

FIG. 10 Impact testing machine

Specific gravity of fine aggregates using pycnometer-

Pycnometer is a glass jar having capacity of 1 litre having a brass conical screw arrangement with $6 \mathrm{~mm}$ diameter hole at the top. Take about $500 \mathrm{~g}$ of sample and place it in the pycnometer. Pour distilled water into it until it is full. Eliminate the entrapped air by 
rotating the pycnometer on its side, the hole in the apex of the cone being covered with a finger. Wipe out the outer surface of pycnometer and weigh it (W). Transfer the contents of the pycnometer into a tray, care being taken to ensure that all the aggregate is transferred. Refill the pycnometer with distilled water to the same level. Find out the weight (W1).Absorb water from the sample through a filter paper. Place the sample in oven in a tray at a temperature of $100^{\circ} \mathrm{C}$ to $110^{\circ} \mathrm{C}$ for $24 \pm 0.5$ hours, during which period, it is stirred occasionally to facilitate drying. Cool the sample and weigh it (W2).

Specific gravity $=($ weight of dry sample/weight of equal volume of water)

$=\mathrm{W} 2 /(\mathrm{W} 2-(\mathrm{W}-\mathrm{W} 2))=\mathbf{2 . 6 2}$

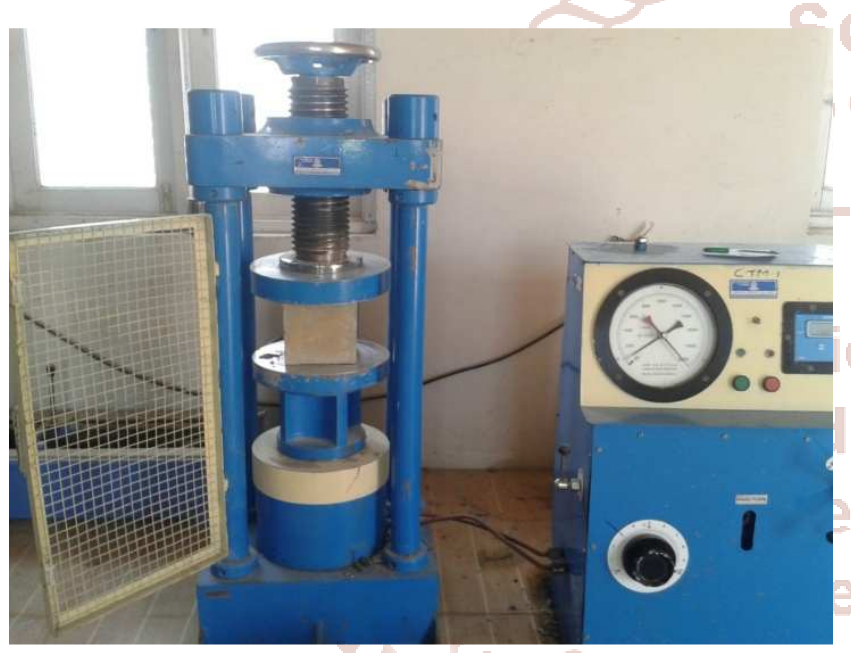

FIG 1 Compressive strength test of cube using CTM.

\section{EXPERIMENTATION}

\section{M-50 CONCRETE MIX DESIGN}

\section{A-1 Stipulations for Proportioning}

1. Grade Designation

2. Type of Cement

3. Maximum Nominal Aggregate Size

4. Minimum Cement Content

5. Maximum Water Cement Ratio

6. Workability (Slump)

7. Type of Aggregate Angular Aggregate

8. Maximum Cement Content

\section{A-2 Test Data for Materials}

1. Cement Used

2. Sp. Gravity of Cement

M50

PPC

$20 \mathrm{~mm}$

$310 \mathrm{~kg} / \mathrm{m}^{3}$

0.30

$50-75 \mathrm{~mm}$

3. Sp. Gravity of Water

4. Sp. Gravity of $20 \mathrm{~mm}$ Aggregate

5. Sp. Gravity of Sand

Crushed

$310 \mathrm{~kg} / \mathrm{m}^{3}$

PPC

3.15
A-3 Target Strength for Mix Proportioning

1. Target Mean Strength $50+(5 X$ $1.65)=58.25 \mathrm{~N} / \mathrm{mm}^{2}$

2. Characteristic Strength @ 28 days $50 \mathrm{~N} / \mathrm{mm}^{2}$

A-4 Selection of Water Cement Ratio

1. Maximum Water Cement Ratio $\quad 0.30$

2. Adopted Water Cement Ratio $\quad 0.35$

A-5 Selection of Water Content

1. Maximum Water content (10262-table-2) $186 \mathrm{Kg} / \mathrm{m}^{3}$

2. Estimated Water content for $50-75 \mathrm{~mm}$ Slump $197 \mathrm{Kg} / \mathrm{m}^{3}$

\section{A-6 Calculation of Cement Content}

1. Water Cement Ratio

2. Cement Content (197/0.35)

0.30

This is greater than $400 \mathrm{~kg} / \mathrm{m} 3$

\section{A-7 Proportion of Volume of Coarse Aggregate \&} Fine Aggregate Content

3. Vol. of C.A. as per table 3 of IS $10262 \quad 62.00 \%$

4. Adopted Vol. of Coarse Aggregate $62.00 \%$

5. Adopted Vol. of Fine Aggregate (1-0.62) $38.00 \%$

\section{A-8 Mix Calculations}

1. Volume of Concrete in $\mathrm{m}^{3} \quad 1.00$

2. Volume of Cement in $\mathrm{m}^{3} \quad 1.046$

(Mass of Cement) / (Sp. Gravity of Cement) x1000

3. Volume of Water in $\mathrm{m}^{3} \quad 0.66$

(Mass of Water) / (Sp. Gravity of Water) x1000

4. Volume of All in Aggregate in $\mathrm{m}^{3} \quad 6.26$

5. Volume of Coarse Aggregate in $\mathrm{m}^{3} 3.530$

6. Volume of Fine Aggregate in $\mathrm{m}^{3} \quad 2.73$

7. Volume of Admixture $0.0043 \mathrm{~m}^{3}$

A-9 Mix Proportions for One Cum of Concrete (SSD Condition)

1. Mass of Cement in $\mathrm{kg} / \mathrm{m}^{3} \quad 310$

2. Mass of Water in $\mathrm{kg} / \mathrm{m}^{3}$

197

3. Mass of Fine Aggregate in $\mathrm{kg} / \mathrm{m}^{3} \quad 809.62$

4. Mass of Coarse Aggregate $\mathrm{kg} / \mathrm{m}^{3}$

1046.22

5. Water Cement Ratio

0.30

M50

Is a construction material that consists of cement

(commonly Pozolonic Portland cement) aggregate (generally gravel and sand), water and admixtures. Engineers usually specify the required compressive strength if concrete, which is normally given as 28 days compressive strength in mega Pascal's or found 
per square inch. 28 days is a long time to determine if desire strength are going to be obtained, so 3 days 7 days and 14 days strength can be useful to predict the ultimate compressive strength of concrete. Portable water can be used for manufacturing concrete. The water cement ratio is a key factor to determine the strength if concrete.

REQUIREMENTS OF CONCRETE MIX DESIGN:The requirement which form the basis of selection and proportioning of mix ingredients are:

$>$ The minimum compressive strength required from structural consideration.

$>$ The adequate workability necessary for full compaction with the compacting equipment available.

$>$ Maximum water cement ratio or maximum cement content to give adequate durability for particular site condition

FACTOR TO BE COSIDERED FOR MIX DESIGN

$>$ The grade designation giving the characteristic strength requirement of concrete.

$>$ The type of cement influences the rate of development of compressive strength of concrete.

$>$ Maximum nominal size of aggregate to be used in concrete may be as large as possible within the limits prescribed by IS 456: 2000.

$>$ The cement content is to be limited from shrinkage, cracking and creep.

$>$ The workability of concrete for satisfactory placing and compaction is related to size and shape so section and quantity or spacing of reinforcement and technique used for transportation, placing and compaction

\section{TYPES OF MIXES}

NOMINAL MIX: In the past the specification for concrete prescribed the proportion so cement, fine aggregates and coarse aggregates. These mixes of fix cement aggregate ratio which ensure adequate strength are termed as nominal mix. These offer simplicity and under normal circumstances, have a margin of strength above that specified. However, due to the variability of mix ingredients the nominal concrete for a given workability varies widely in strength.

STANDARD MIXES: The nominal mixes of fixed cement aggregate ratio vary widely in strength and may result under or over rich mixes. For this reason, the minimum compressive strength has been included in many specifications. These mixes are termed standard mixes. IS456: 2000 has designated the concrete mixes into no. of grades as M10, M15, M20, M30, M35, M45 and M50. In these deviations the letter $M$ refers to the mix and the no. to the specified 28 days cube strength of mix in newt on per $\mathrm{mm}$ square.

DESIGN MIXES: In these mixes the performance of concrete is specified by the designer but the mix proportion are determined by the producer of concrete except the minimum cement content can be laid down. This is most rational approach in the selection of mix proportion with specific material in mine possessing more or less unique characteristics. The approach results in production of concrete with the approx. properties most economically. However, the design mix does not serve as a guide since this does not guarantee the concrete mix proportion for the prescribed performance. For the concrete with understanding performance nominal or standard mixes may be used only for small jobs, when 28 days strength of concrete does not exceed $50 \mathrm{~N} / \mathrm{mm}^{2}$.

\section{FACTORS AFFECTING CHOICE OF MIX PROPORTION}

COMPRESSIVE STRENGTH: It is one of the most important properties of concrete and influences many other properties of hardened concrete. The main compressive strength required at the specified age, usually 28 days, determines the nominal water cement ration of the mix. The other factor affection the strength if concrete at a given age and cured at a prescribed temperature is the degree of compaction.

WORKABILITY: The degree of workability required depends on 3 factor. These are a side of section to be concreted, the amount of reinforcement and the method of compaction to be used. For the narrow and complicated section with numerous corners or inaccessible parts, the concrete must have a high workability so that full compaction can be achieved with reasonable amount of efforts. This also applies to the embedded steel sections.

DURBILITY: The durability of concrete is its resistance to the aggressive environmental conditions. High strength concrete is generally more durable than low strength concrete. In the situation when the high strength concrete is not necessary but the condition of exposure are such that high durability is vital, the 
durability requirement determine the water cement ratio to be used.

MAXIMUM NOMINAL SIZE OF AGGREGATE: In general larger the maximum size of aggregate, smaller is the cement requirement for a particular water cement ratio, because the workability of concrete increases with the maximum size of aggregate. However, the compressive strength tends to increase with decrease in size of aggregate.

MIXING OF CONCRETE- through mixing of ingredients is essential for production of uniform concrete. The mixing of ingredients should ensure that concrete mix becomes homogeneous uniform in colour.

Mixing is done by two methods-
A. Hand mixing.
B. Machine mixing.

We have done machine mixing. In mixing firstly cement, sand and aggregates are mixed in dry state for 1-2 minutes and then water is added to it in specified proportion as per mix design. All the material is then mixed for 2- 3 minutes and then glass fibre is added and mixed for 1 more minute. The concrete is then taken out and cubes are casted.

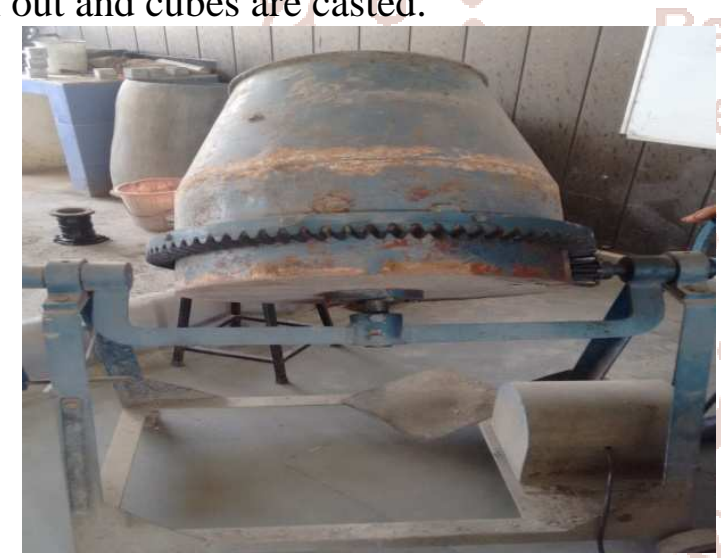

Fig12 concrete mixer

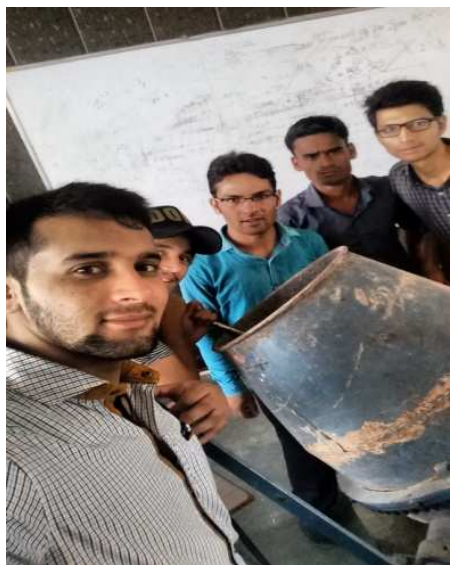

Fig 13mixing of concrete
4.2 CUBE CASTING-

Apparatus:

$>$ Cube Mould (150x150x150 mm)

$>$ Tamping bar (16 $\mathrm{mm}$ diameter and bull-nosed)

$>$ Steel Float/Trowel

\section{Procedures of Making Concrete Cube:}

Making concrete-cube specimen is simple and it is done in three simple steps.

1. Cleaning \& Fixing mould,

2. Placing, Compacting \& Finishing concrete, and

3. Curing.

\section{Cleaning \& fixing mould}

Clean the cube-mould properly and apply oil on inner surface of mould. But no oil should be visible on surface.

Fix the cube mould with base plate tightly. No gap should be left in joints so that cement-slurry doesn't penetrate.

Place the mould on levelled surface. (a)
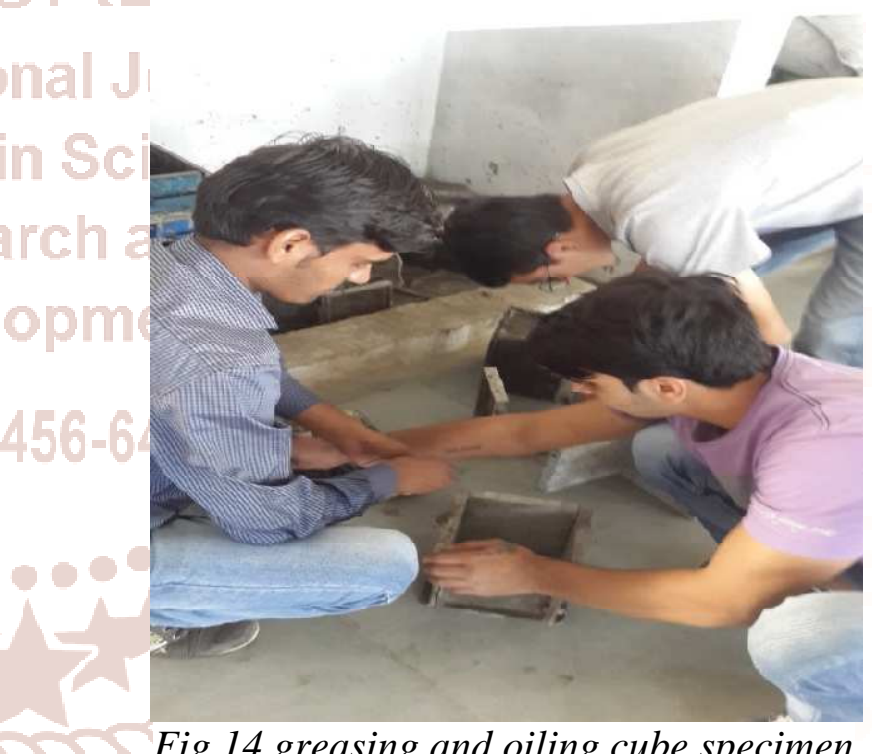

Fig.14 greasing and oiling cube specimen

\section{Placing, Compacting \& Finishing concrete}

$>$ Take concrete from three or four random mixes.

$>$ Place concrete into mould in three layers. Compact each layer by giving 35 blows of tamping bar.

$>$ Remove excess concrete from the top of mould and finish concrete surface with trowel. Make the top surface of concrete cube even and smooth.

$>$ Left the mould completely undisturbed for first four hours after casting.

$>$ After ending undisturbed period, put down casting date and item name on the top of concrete specimen with permanent marker. 


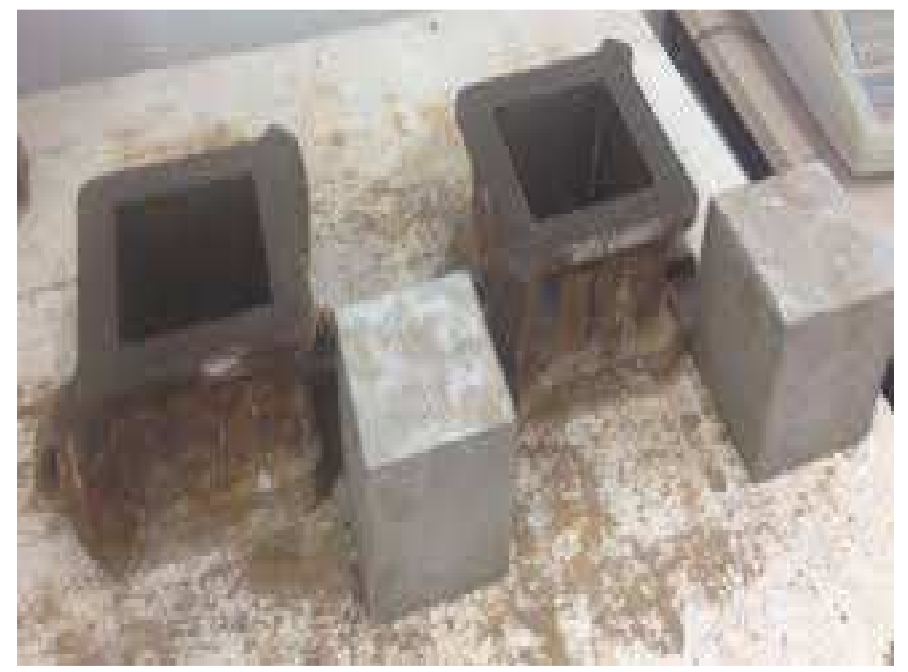

Fig- 15 concrete cubes

1. Remove the specimen from water after specified curing time and wipe out excess water from the surface.

2. Take the dimension of the specimen to the nearest $0.2 \mathrm{~m}$

3. Clean the bearing surface of the testing machine

4. Place the specimen in the machine in such a manner that the load shall be applied to the opposite sides of the cube cast.

5. Align the specimen centrally on the base plate of the machine.

6. Rotate the movable portion gently by hand so that it touches the top surface of the specimen.

7. Apply the load gradually without shock and continuously at the rate of $140 \mathrm{~kg} / \mathrm{cm} 2 /$ minute till the specimen fails

3. Curing After 8 to 10 hours of casting, wrap the cube mould with wetted hessian cloth. Cover the mould's top portion with a polythene sheet so that water doesn't fall on concrete surface. Uncover and remove the cube specimens from mould after $24 \pm 1 / 2$ hours of casting. For removing specimen from mould, first loosen all nut-bolts and carefully remove specimen because concrete is still weak and can be broken. Immediately after removing, put the specimen into a tank of clean water for curing. Make sure cube specimen is fully submerged in water .After 28 days of curing take out specimens from water tank and send to laboratory for testing.

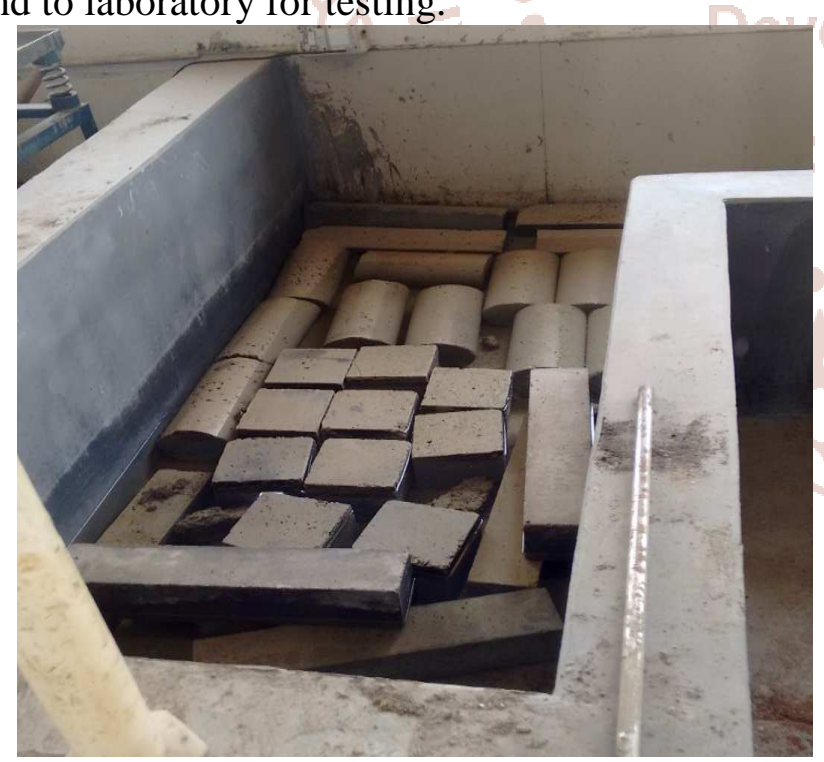

Fig.16 curing

4.3 Compressive strength test- this is the test for checking the compressive strength of cubes and generally performed after $3,7,14,28$ days of curing of cubes. This test is performed on compression testing machine.

8. Record the maximum load and note any unusual features in the type of failure.

Minimum three specimens should be tested at each selected age. If strength of any specimen varies by more than 15 per cent of average strength, results of such specimen should be rejected. Average of there specimens gives the crushing strength of concrete. The strength requirements of concrete.

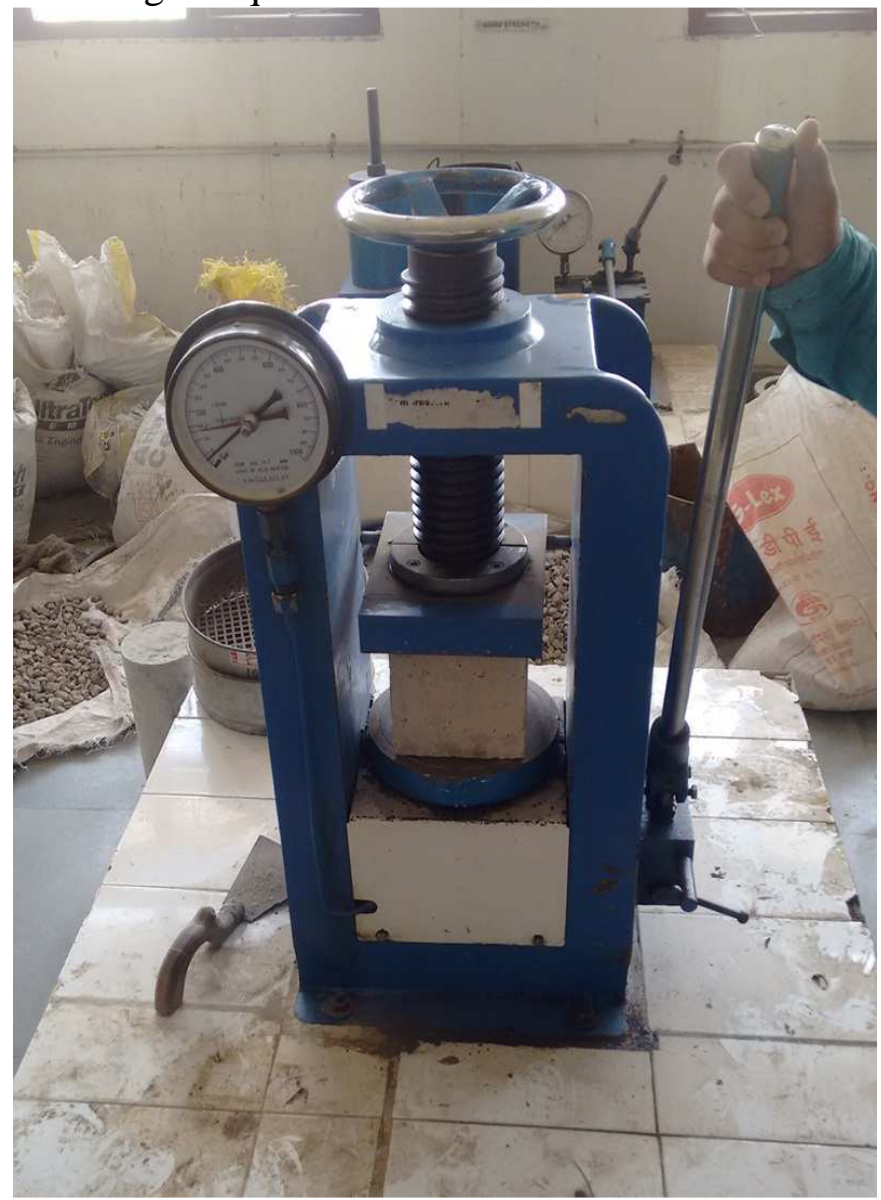

Fig.17 testing of cubes for compressive strengtgh 
International Journal of Trend in Scientific Research and Development (IJTSRD) ISSN: 2456-6470

READINGS:-The readings of the performed tests are as below:-

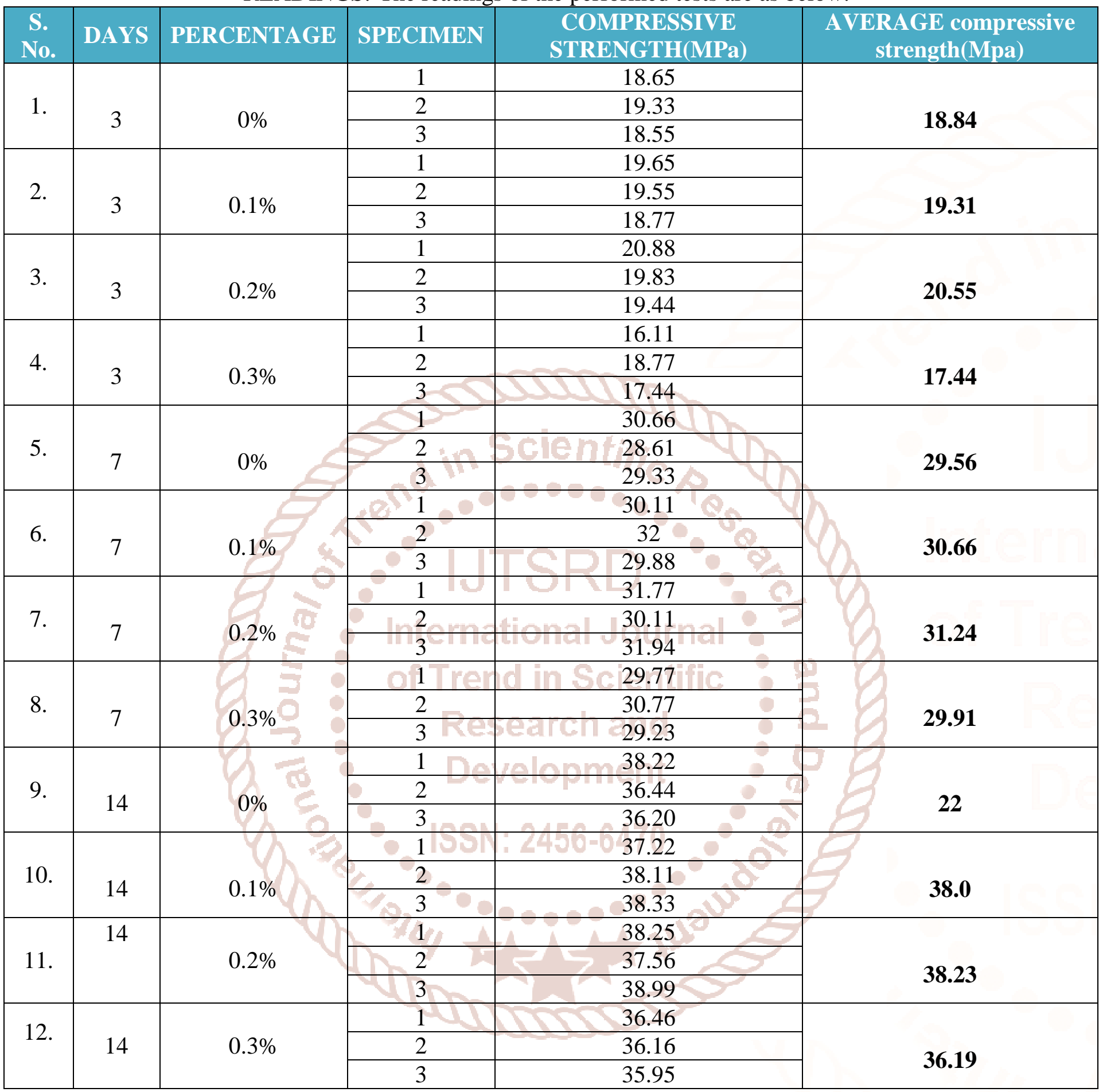

\section{RESULT ANALYSIS}

1. The average compressive strength of the normal cubes was 18.84 MPa after 3 days.

2. The average compressive strength of the $0.1 \%$ polypropylene cubes was 19.31 MPa after 3 days.

3. The average compressive strength of the $0.2 \%$ polypropylene cubes was $20.55 \mathrm{MPa}$ after 3 days.

4. The average compressive strength of the $0.3 \%$ polypropylene cubes was 17.44 MPa after 3 Days

5. The average compressive strength of the normal cubes was 29.56 MPa after 7 days
6. The average compressive strength of the $0.1 \%$ polypropylene cubes was 30.66 MPa after 7 Days

7. The average compressive strength of the $0.2 \%$ polypropylene cubes was 31.24 MPa after 7 Days

8. The average compressive strength of the $0.3 \%$ polypropylene cubes was 29.91 MPa after 7 Days

9. The average compressive strength of the normal cubes was37.08 MPa after 14 days

10. The average compressive strength of the $0.1 \%$ polypropylene cubes was 37.88 MPa after 14 Days 
11. The average compressive strength of the $0.2 \%$ polypropylene cubes was 38.23 MPa after 14 Days

12. The average compressive strength of the $0.3 \%$ polypropylene cubes was 36.19 MPa after 14 days

\section{REFERENCES}

1. A Study on Glass Fibre as an Additive in Concrete to Increase Concrete Tensile Strength: https://www.researchgate.net/publication/2811784 45.

2. Experimental Studies on Glass Fiber Concrete. American Journal of Engineering Research (AJER) e-ISSN: 2320-0847 p-ISSN : 2320-0936

3. STUDIES OF GLASS FIBER REINFORCED CONCRETE COMPOSITES. ISSN 2319 - 6009 www.ijscer.com Vol. 2, No. 3, August 2013 (c) 2013 IJSCER

4. Experimental studies on fiber reinforced concrete. Utkarsh R. Nishane. Int. Journal of Engineering
Research and Application www.ijera.com ISSN : 2248-9622, Vol. 7, Issue 5, ( Part -2) May 2017, pp.40-44

5. Study of Glass Fibre Reinforced Concrete IOSR Journal of Mechanical and Civil Engineering (IOSR-JMCE) e-ISSN: 2278-1684,p-ISSN: 2320334X, Volume 13, Issue 3 Ver. VI (May- Jun. 2016), PP 58-61

6. SSRG International Journal of Civil Engineering (SSRG-IJCE) -volume 3 Issue 5-May 2016

7. I international Journal of Engineering Trends and Technology (IJETT) -Volume-43 Number- 7 January 2017

8. Umapathy $U$ et al Int. Journal of Engineering Research and Applications ISSN : 2248-9622, Vol. 4, Issue 5( Version 1), May2014, pp.72-76

9. IJSRD -International Journal for Scientific Research \& Development| Vol. 2, Issue 05, 2014| ISSN (online): 2321-0613 